\title{
Restoring forests: regeneration and ecosystem function for the future
}

\author{
Magnus Löf ${ }^{1} \cdot$ Palle Madsen ${ }^{2} \cdot$ Marek Metslaid $^{3,4}$ - Johanna Witzell ${ }^{1}$. \\ Douglass F. Jacobs ${ }^{5}$
}

Published online: 28 March 2019

(c) Springer Nature B.V. 2019

\begin{abstract}
Conventions and policies for biodiversity conservation and climate change mitigation state the need for increased protection, restoration and climate change adaptation of forests. Much degraded land may be targeted for large-scale forest restoration, yet challenges include costs, a shortage of regeneration material and the need for restored forests to serve as a resource for communities. To ensure ecosystem function for the future, forest restoration programs must: (1) learn from the past; (2) integrate ecological knowledge; (3) advance regeneration techniques and systems; (4) overcome biotic and abiotic disturbances and (5) adapt for future forest landscapes. Historical forest conditions, while site-specific, may help to identify the processes that leave long-term legacies in current forests and to understand tree migration biology/population dynamics and their relationship with climate change. Ecological theory around plant-plant interactions has shown the importance of negative (competition) and positive (facilitation) interactions for restoration, which will become more relevant with increasing drought due to climate change. Selective animal browsing influences plant-plant interactions and challenges restoration efforts to establish species-rich forests; an integrated approach is needed to simultaneously manage ungulate populations, landscape carrying capacity and browse-tolerant regeneration. A deeper understanding of limiting factors that affect plant establishment will facilitate nursery and site preparation systems to overcome inherent restoration challenges. Severe anthropogenic disturbances connected to global change have created unprecedented pressure on forests, necessitating novel ecological engineering, genetic conservation of tree species and landscape-level approaches that focus on creating functional ecosystems in a cost-effective manner.
\end{abstract}

Keywords Afforestation - Land-use · Multiple-use forestry · Reforestation · Resilience · Sustainable forest management

Magnus Löf

magnus.lof@slu.se

Extended author information available on the last page of the article 


\section{Need for forest restoration programs, and purpose of the congress}

Forests around the globe provide a wide variety of ecosystem services. International conventions and national policies for biodiversity conservation and climate change mitigation state the need for increased forest protection, forest restoration and adaptation of forest management to climate change. However, global forest cover continues to decline. According to the last Forest Resources Assessment, the world's forest area decreased by ca 3\% between 1990 and 2015 (FAO 2018). Against this background, forest restoration activities have become increasingly common around the world and regeneration of trees is often a key component in these projects. Much degraded land may be targeted for forest restoration. In an analysis from 2011, the World Resource Institute suggested that ca 2 billion hectares of land is suitable for different kinds of forest restoration (Minnemayer et al. 2011; Silva et al. 2019).

Several global, regional and national organizations have set targets during the last decade for large-scale forest landscape restoration. For example, the Great Green Wall of the Sahara and the Sahel Initiative in Africa aim to surround the region with vegetation, and China alone aims to plant 6.7 million hectares of forest per year (Cernansky 2018). The Bonn Challenge, started in 2011, aims to have 150 million hectares of degraded land in process of restoration by 2020 , and 350 million hectares by 2030 according to the New York Declaration of 2014. Additionally, the UN REDD + program is attempting to encourage restoration of forests by creating a market value for the carbon stored therein (Jacobs et al. 2015). The United Nations recently recognized the critical role of ecosystem restoration as a tool for improving environmental conditions and enhancing human communities by designating 2021-2030 the UN Decade of Ecosystem Restoration (UN 2019). Restoration ambitions are high, and these initiatives have received much support from countries and organizations around the world.

Successful large-scale restoration faces many challenges. First, the costs of achieving restoration are often high. A conservative estimate of 2000 \$USD per hectare means that at least 700 billion \$USD is required to restore 350 million hectares by 2030. This represents a significant barrier for scaling up restoration worldwide and there is a risk that the interest from policymakers will wane over time as the costs and difficulties becomes apparent (Löf 2017). Restoration costs vary depending on methods used, from lower-cost alternatives using natural regeneration with native tree species to higher-cost approaches for active restoration using site preparation and planting. Recently, there has been a debate regarding advantages, disadvantages and the degree of success with these approaches (e.g. Crouzeilles et al. 2017; Meli et al. 2017; Reid et al. 2018) but no one-size-fits all solution regarding methods for restoration exists. Instead a broad palette of methods adapted to the local context needs to be utilized to accomplish the ambitious targets. Normally, costs for restoration increase with the degree of degradation of an ecosystem (Stanturf et al. 2001; Chazdon 2008) (Fig. 1). Thus, if appropriate seed sources are available, natural regeneration with native tree species may represent a cost-effective option that may be applied across large areas. In other cases, when no such seed sources exist or when sites are too harsh, active restoration using planting (sometimes with non-natives) is the only option to establish forests (Jacobs et al. 2015).

Second, an important obstacle for successful active restoration is often a shortage of regeneration material (Cernansky 2018). Restoration projects involve the re-establishment of native tree species, but there is often little knowledge about how, where and when to obtain genetic material (species and provenances) with desired properties 


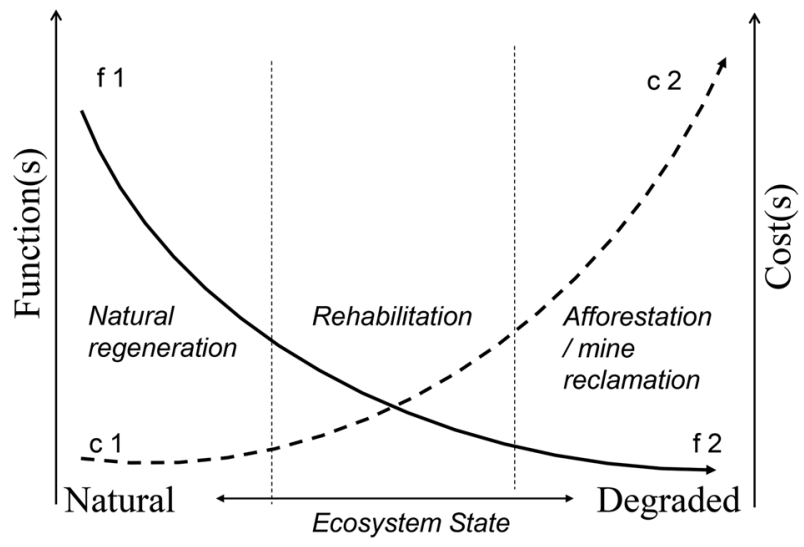

Fig. 1 A model for restoration, degradation and costs (adapted from Stanturf et al. 2001). The state of the forest condition ranges from natural to degraded (x-axis) and levels of ecosystem function (left $y$-axis) change in response to disturbance along a solid line (f1-f2). Cost of forest restoration (right y-axis) follows the dashed line (c1-c2). The costs increase with degree of degradation, e.g. higher costs using artificial regeneration (direct seeding, and especially high costs during planting) when less mother trees are available during afforestation and mine reclamation. When the degree of degradation is lower, i.e. when scattered trees and near-natural forests are left; restoration can rely on low-cost natural regeneration

for the sites under restoration, and how to collect, store and pretreat seeds followed by cost-efficient cultivation of the seedlings in nurseries. In addition, we have little experience with establishing such regeneration; efficient regeneration systems currently exist for only a few tree species, mostly for use in industrial plantations and these techniques are not always suited for restoration programs (Löf et al. 2012). In addition, climate change raises questions about where different tree species may thrive in the future. Assisted migration, i.e. the human-assisted movement of plants or animals to more climatically suitable habitats, may be one way forward (Stanturf et al. 2014a, b; Dumroese et al. 2015). Much knowledge in this field is, however, still missing. The same can be said about how climate change will alter relationships among trees, insects and various diseases.

A third major constraint for successful cost-effective restoration in the long term is that the restored forests needs to be a positive resource for the local and regional communities. Thus, forest restoration success depends much on people and their ability to utilize restored forests in different ways. The mounting demands from a growing human population increase the already huge pressure on the world's natural resources. If society's needs are not considered, the risk is that public interest to protect forests in a sustainable way will be insufficient. Multiple-use forestry, such as with multi-purpose mixed forest systems and agroforestry systems that provide food and other benefits for people, is therefore important. In addition, increasing evidence suggests that integrating exotic commercial tree species with native ones can support biodiversity, the environment and local economies. One such approach is the new generation plantation (NGP) Platform that was launched in 2007 (Silva et al. 2019). This concept aims to complement timber production with effective maintenance and enhancement of ecosystems, and simultaneously contribute to socio-economic development and climate change mitigation (Fig. 2). Plantations, with a current share of ca $7 \%$ of total global forests, can help to reduce pressure on natural forests (FAO 2010) as they contribute to ca $33 \%$ of global 

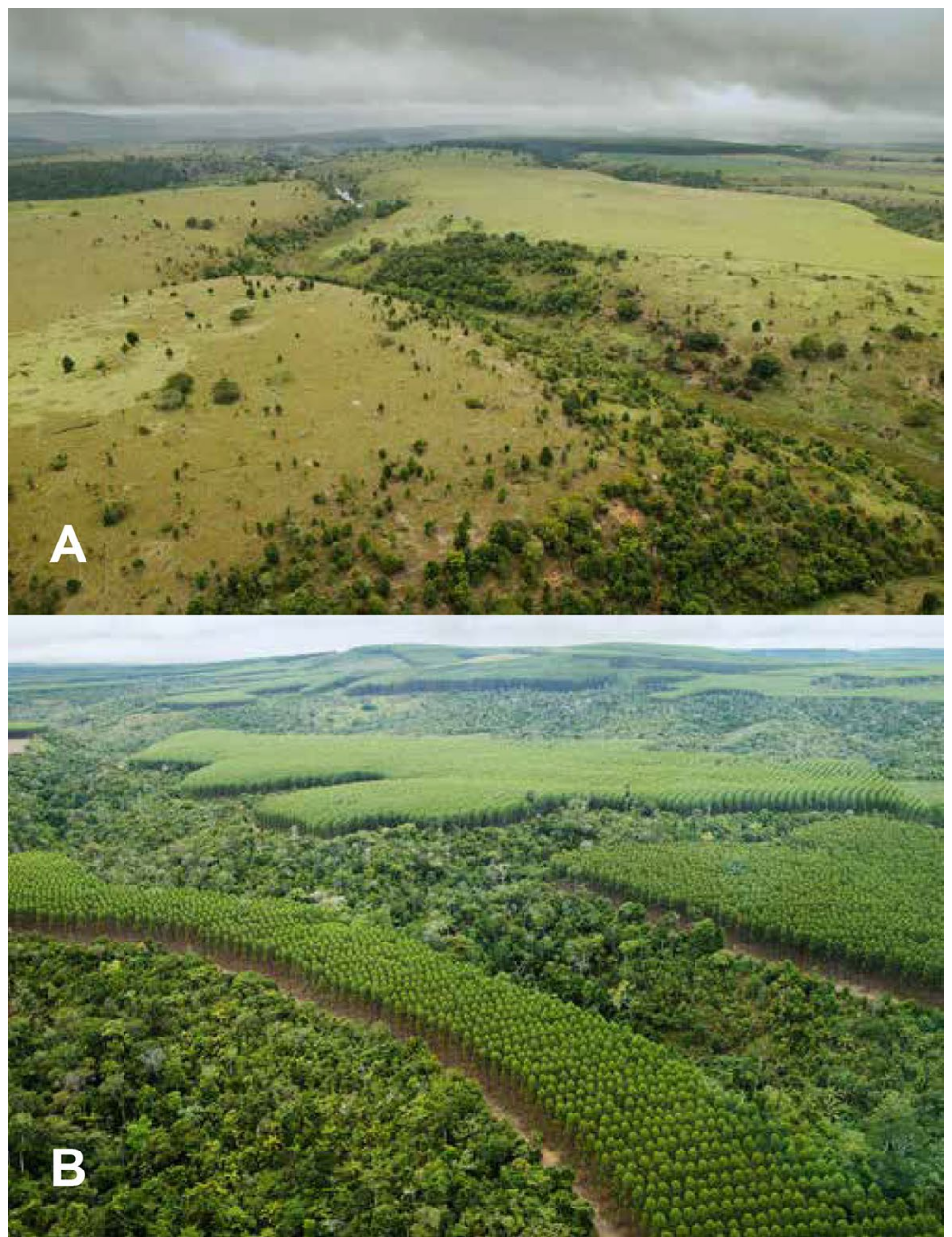

Fig. 2 Example of a new generation plantations initiative by Veracel in Bahia, Brazil where a degraded rain forest dominated landscape (a) can be restored with native tree species forming ecological corridors of rain forest in-between highly productive eucalyptus plantations (b) (Copyright Stora Enso)

demand for industrial round wood, a demand that is predicted to increase (Silva et al. 2019). The NGP concept is one way to, at least partly, meet these growing demands.

In September 2011, we held the 1st IUFRO Restoring Forests Congress in Madrid, Spain to address recent advances in forest restoration techniques and theory. Selected papers from this symposium were published in New Forests (vol. 43, Issues 5-6). The 2nd IUFRO Restoring Forests Congress occurred in October 2014 in Indiana, USA and the corresponding Special Issue of this symposium was published in New Forests (vol. 46, Issues 5-6). To continue to communicate and advance upon emerging issues and themes in forest restoration, we held the 3rd IUFRO Restoring Forests Congress on 12-14 September 2017 in Lund, Sweden. The symposium was organized by the 
Swedish University of Agricultural Sciences and Southern Swedish Forest Research Centre, Estonian University of Life Sciences, University of Copenhagen and Purdue University, as well as IUFRO Divisions 1.01.00 (Temperate and Boreal Silviculture), 1.06.00 (Restoration of Degraded Sites), 2.01.15 (Whole Plant Physiology), and 1.01.06 (Ecology and Silviculture of Oak). A total of 109 scientists, representing 31 countries in five continents attended the Congress, which included 12 invited seminars, 38 offered oral presentations and 46 poster presentations. Field tours to Söderåsens National Park and Herrevads Monastery area highlighted ongoing research and management programs to promote forest restoration of broadleaves. The overall theme of the $3^{\text {rd }}$ Congress was Restoring Forests-Regeneration and Ecosystem Function for the Future. The Congress was arranged according to the following five topics/sessions and within each topic, several key issues emerged (see below-Focal topics of the congress): (1) learning from the past; (2) ecological knowledge supporting forest restoration; (3) advances in restoration and regeneration techniques and systems; (4) forest restoration following biotic and abiotic disturbances; and (5) restoring forest landscapes for the future. The purpose of this international congress was to support this process by knowledge sharing and communication of the state-of-the-art in the research field of regeneration and forest restoration ecology.

\section{Focal topics of the congress}

The Congress was arranged according to the following centralized topics, and within each topic, several key issues emerged.

\section{Learning from the past}

Scientists in restoration ecology continue to debate the usefulness of historical ecosystem conditions as targets and reference for practical restoration (e.g. Harris et al. 2006; Corlett 2016). An ecosystem condition is a response to past land use and past climate; restoring ecosystems is unlikely to be easy or even possible, especially under a rapidly changing climate. Even though historical conditions may, however, not always be useful as targets, research into long-term forest dynamics can support forest restoration in many ways. During this session, Richard Bradshaw listed three topics of major importance for restoration (Löf 2017). First, past historical forest conditions are often site-specific. Human pressure on forests may have varied much between sites and landscapes and, thus, restoration practitioners must be aware of this when defining any restoration targets. Second, through studies of the past we may identify the processes that leave long-term legacies in current forests (Johnstone et al. 2016; Jõgiste et al. 2017). Human impact through forest management and land-use patterns strongly influence current forest dynamics (Giesecke et al. 2017). For example, past forest fire regimes have been greatly altered by human activity; humans first greatly increased fire frequency and subsequently almost eradicated fire in parts of the world, therefore possibly influencing the fire regime to an extent that may be unprecedented for millennia (Krawchuk et al. 2009; Bradshaw and Sykes 2014). Similarities exist for past browsing and grazing regimes by both domestic animals and wild ungulates. Finally, understanding tree migration biology and population dynamics and their relationship with climate change is important. It can be very expensive for restoration practitioners trying to resist natural trends in forest dynamics. Restoration strategies should therefore 
look forward to solve future needs of society, but their success will be enhanced by looking backwards on information about the outcomes of past human impact, climate dynamics and forest response.

\section{Ecological knowledge supporting forest restoration}

During the last two decades, ecological theory concerning plant-plant interactions has developed with potential for great implications for cost-effective restoration (Löf 2017). In particular, it has been stressed that negative (competition) and positive (facilitation) interactions co-exist to a larger degree than previously thought (e.g. Bruno et al. 2003). Earlier, there was a strong focus on negative interactions, and still the most common vegetation management techniques during regeneration and restoration are measures that reduce competition from non-desired vegetation. Examples of such measures include prescribed fire, herbicides and mechanical site preparation. Concepts, such as the stress-gradient-hypothesis (e.g. Bertness and Callaway 1994; He et al. 2013) and nurse-plants (e.g. Gómez-Aparicio 2009) have, however, the potential to guide restoration toward methods that improve seedling survival and growth while simultaneously keeping restoration costs low. The former concept states that facilitation relative to competition increases in importance with the degree of abiotic and biotic stress, and the latter that one plant species can facilitate growth and development of another species. In addition, managing plant-plant interactions for restoration will be particularly relevant in scenarios of increasing drought due to climate change, with potential for an increasing role of facilitation to secure regeneration. However, these concepts have so far most frequently been applied to restoration in dry land ecosystems dominated by perennial herbs or shrubs (Gómez-Aparicio et al. 2004). Knowledge is still lacking for forest ecosystems where vegetation dynamics are more complex, i.e. temperate or tropical regions. To succeed, it is not only necessary to select good combinations of nurse- and target-tree species with complementary species traits, but also to manage plant densities and community composition as plant cover and competition increase with time.

Direct or indirect biotic interactions involving herbivores may also play a fundamental role for cost-effective forest restoration. High deer populations in Europe and North America, for example, pose one of the greatest challenges to the forest regeneration of many plant species, which further affects species composition, forest structure and function (e.g. Côté et al. 2004). Selective ungulate browsing influences plant-plant interactions to such an extent that browse-tolerant or less palatable tree species often are favored and, thus, challenge restoration efforts to establish more species-rich forests (Kuijper et al. 2010; Metslaid et al. 2013). Physical or chemical protection of regeneration by fences, repellents or individual tree shelters is usually effective, but the costs of establishing, maintaining and removing these measures are high. Low-cost strategies may include providing physical protection for the target trees by using dense natural regeneration, direct seeding of species that are more browse tolerant or using nurse trees/shrubs. Ungulate impact can also be lessened by reducing the populations (by hunting), increasing the forest landscape carrying capacity (more food for the deer) or combining these two approaches. In addition, fodder crops of grasses, herbs or woody species, may be established to release browsing pressure from more desired species on restoration sites; and supplementary feeding might be an option if this food improves nutrition of the ungulate (Felton et al. 2016). However, it may be difficult to translate new research findings about low-cost browsing-tolerant regeneration alternatives to restoration practice. An integrated approach is needed that simultaneously 
manages populations of deer, landscape carrying capacity and browsing-tolerant regeneration, which requires good cooperation among various stakeholders.

\section{Advances in restoration and regeneration techniques and systems}

Forest restoration and regeneration practices must continuously adapt to meet changing needs of society, human and natural disturbances, policies, markets, technologies and climate (Wagner et al. 2018). Much of the past science in this area emphasized reforestation following timber harvest for industrial purposes, but an increasing focus on restoration of harsh, degraded environments demands new seedling production and planting techniques (Oliet and Jacobs 2012). Improved understanding of biotic and abiotic factors that affect ecophysiology of plant establishment is required to overcome inherent challenges on restoration sites. Nursery systems aim to produce high quality, stress resistant planting stock that will withstand stresses following field establishment (Haase and Davis 2017). Stocktypes, fertilization or irrigation regimes and hardening practices can be manipulated in the nursery to tailor morphological and physiological seedling attributes to optimize performance under the conditions of a given outplanting site (Grossnickle and El-Kassaby 2015; Dumroese et al. 2016). Seedling size is positively correlated with plant content of nitrogen and carbohydrates and seedlings may remobilize these stored reserves in order to resist environmental stresses on the planting site (Villar-Salvador et al. 2015; Uscola et al. 2015). Thus, while a shift away from planting older and larger seedlings toward younger and smaller seedlings has occurred in some boreal regions (Löf 2017), the opposite trend prevails for restoration under harsh, dry site conditions, such as in Mediterranean regions (Villar-Salvador et al. 2012).

Site preparation is often necessary on restoration sites to ensure natural or artificial regeneration success, with requirements often dependent upon severity of prior disturbance. For instance, severe landscape disturbance associated with mine reclamation may require novel innovations in geomorphic restoration and site reconstruction (MacDonald et al. 2015; Zapico et al. 2018) to ensure functioning soil. Technological advances of mechanical site preparation have improved the efficiency of control of site limiting factors (i.e. target vegetation, compaction, mounding), costs, environmental impact and worker safety (Löf et al. 2012; Löf 2017). Continued enhancements in application of field fertilization, soil amendments and tree shelters (Earnshaw et al. 2016; Löf 2017; Oliet et al. 2019) will further promote regeneration and restoration success. While fencing is generally effective against ungulate damage, the high cost of installation and maintenance limits its practical use. Thus, continued evaluation of alternatives such tree shelters, nurse plants and silvicultural planting schemes that account for browse risk (Owings et al. 2017; Burney and Jacobs 2018; Maltoni et al. 2019) will help to ensure cost-effective restoration.

\section{Forest restoration following biotic and abiotic disturbances}

Disturbances are an essential part of forest ecosystems. Ecological processes that lead to stand structural complexity are in fact dependent upon natural disturbances (Löf 2017), which may include windthrow, forest fire and pest or disease outbreaks. Although the economics of fiber production is the main driver of management in commercial forests, there are opportunities to use alternative forestry methods, such as retention trees, variable density thinning and prescribed burning that mimic natural disturbances to promote heterogeneous forest stand structure and biodiversity (Puettmann et al. 2016; Löf 2017). 
Degradation and loss of forests due to anthropogenic disturbances, however, have resulted in a significant reduction of forest biodiversity and the need for restoration of millions of hectares of degraded forests worldwide (Lindenmayer 2019). In degraded environments, such as with grazing lands, abandoned crop lands or following severe wildfire, structural elements and sources of microsite diversity are often limited (Cortina et al. 2011), adding to restoration challenges. Mining sites are particularly difficult to restore to functioning forest ecosystems because of the need for massive landscape-level reconstruction of soils, hydrology and biota, as well as the associated forest fragmentation, erosion and disposal of mine tailing wastes (Stanturf et al. 2014a, b; Macdonald et al. 2015).

Simultaneously, global change, including an exponential increase in the introduction of invasive species and a rapidly shifting climate puts unprecedented pressure on forests (Martín et al. 2013; Dumroese et al. 2015). The number of threatened and endangered forest tree species continues to rise, and the practical restoration of such species is complex due to the need for effective integration of technology, ecology and society (Jacobs et al. 2013). Thus, the genetic conservation of tree species has become an urgent global necessity as this provides the essential basis for the adaptation and resilience of tree species to environmental stress and change (Potter et al. 2017). While knowledge of historical species range distributions can help to guide restoration targets (Dalgleish et al. 2015), shifts in frost hardiness zones, drought severity indices and presence or absence of species competitors will drive species regional adaptiveness in the future. We are still in the infancy of navigating these dynamic and critical issues that will have long-lasting consequences for success of forest restoration programs.

\section{Restoring forest landscapes of the future}

In addition to goals for mitigating climate change and improving local economies, restoration provides great hope that biodiversity losses can be minimized and sometimes reversed. However, there is a polarized debate among conservation, forest management and restoration in relation to, e.g. non-native species and novel ecosystems, but also any need for continued management (Hobbs 2013). This debate will proceed even though all disciplines will be transformed in order to address rapid climate change both from theoretical- and practical perspectives (e.g. Colloff et al. 2017; Spathelf et al. 2018). The traditional use of past ecosystems as targets and criteria for success will probably be replaced over time by an increased orientation towards an uncertain future. Conflicts are sometimes rooted in discrepancies regarding definitions of concepts, and in other cases concepts are contextdependent (Corlett 2016). For example, retention approaches at final harvest, whereby individual trees, tree patches and dead wood are left on a site with a primary aim to promote biodiversity (Löf 2017), were introduced a few decades ago on several continents. Retention can be seen as a conservation action, as natural forest elements are saved for the future (in a forest landscape previously not much affected by humans). But it can also be seen as restoration because it creates structurally richer stands (in a forest landscape that has been homogenized by human operations, i.e. clearcutting and plantation forestry). Other practices, such as forest enrichment by underplanting, contribute to enhance structural complexity of managed forests yet their effectiveness is dependent upon choice of thinning intensity and underplanted species attributes (Gavinet et al. 2016; Lesko and Jacobs 2018; Lu et al. 2018). Because several disciplines are involved in the discussion, any attempts to formulate a universal definition of restoration will continue to generate discussion (Mansourian 2018; Stanturf et al. 2014a, b). 
Large areas require forest restoration and so landscape-level approaches that focus on functional ecosystems, rather than historical conditions in small areas, may be most costeffective (Stanturf et al. 2014a, b; Perring et al. 2015). In addition, a need to broaden the scope of forest restoration, from the site and stand level to the landscape level, is often required (Gustafson et al. 2018). Otherwise it will be difficult to accommodate diverse objectives from multiple owners and incorporate livelihood needs. The concept of New Generation Plantations (Silva et al. 2019) is one promising way forward, but such multipurpose approaches create new challenges for research and management. While our understanding of mixed forest systems has increased over the last decades, the formulation of silvicultural and restoration guidelines for practical management of more complex forest stands and landscapes is lacking in many cases (Coll et al. 2018). Thus, despite ambitious goals and governmental funding initiatives for restoration including native tree species, such stands may not receive timely thinning treatments for sustained timber production or sustained compositional diversity.

\section{Brief presentation of special issue content}

A total of 12 original research or review articles covering a wide range of issues in forest restoration are included in this Special Issue and some of these are highlighted here. In accordance with his inaugural address from the Congress, Luis Neves Silva describes the potential for new generation plantations (NGP) to conserve natural forests and biodiversity, while also providing timber and helping to mitigate climate change (Silva et al. 2019). Approximately 11.1 million hectares of land are being managed as NGP, which results in economic return while contributing positively to ecosystems and socio-economic development. David Lindenmayer's inaugural address detailed how the case study of Eucalyptus regnans in southeastern Australia can be applied toward four guiding principles that strategically help to conserve biodiversity and accomplish effective forest restoration. These general principles focus on key species and their habitats, attributes of stand structure, landscape heterogeneity and ecological processes (Lindenmayer 2019).

Addressing the theme of Ecological Knowledge Supporting Forest Restoration, Merlin et al. (2019) report results of an experiment conducted in the boreal forests of northern Alberta, Canada on a site that was heavily reconstructed following oil sands mining. They demonstrated the importance of physical and chemical properties of the reconstructed soils as determinants of the performance of planted boreal tree species and how limiting factors to seedling performance may vary by species and shift over time. It is well known that granivorous rodents are a major threat to successful regeneration of broadleaves. To help identify control mechanisms, Villalobos et al. (2019) demonstrated that repellents may help to reduce predation of oak acorns and beech nuts by voles. Meta-analyses provide an important tool to identify generalized trends across research studies globally. In seedling quality and field performance research, however, about one-third of publications cannot be used for such purposes due a lack of methodological details and statistical results. Andivia et al. (2019) present guidelines for improving article presentation so that future research can be more readily incorporated into such meta-analyses.

Oliet et al. (2019) contributed toward the session on Advances in Restoration and Regeneration Techniques and Systems. Tree shelters are commonly used as a means to improve survival of planted seedlings in Mediterranean restoration systems, but the ecophysiological mechanisms for species differences are not well understood. By examining 
solid versus mesh wall tubes that vary in light transmissivity, they concluded that microclimatic factors may primarily drive responses.

Juan A. Martín delivered an invited presentation to launch the session titled Forest Restoration Following Biotic and Abiotic Disturbances. Through traditional hybridization and selection of native clones, significant progress has been made toward restoration of European elms that were devastated by Dutch elm disease (Martín et al. 2019). The researchers recognized the importance of improving knowledge in elm ecology and society's acceptance of disease resistant hybrid elms in order for such species restoration to be successful, similar to the case of American chestnut in the US (Jacobs et al. 2013). As also presented in this session, Anderson et al. (2019) describe accumulation of soil organic matter under re-vegetation treatments following oil sands reclamation in northern Alberta, Canada. They linked treatment differences to varying macro-faunal activity and suggested that planting of aspen would result in more rapid carbon sequestration through soil organic matter accumulation. Berg et al. (2019) studied advance regeneration responses in forest gaps over a 20-year period following hurricane disturbance in the central Appalachian Mountains region of the US. They observed strong temporal variation in tree survival associated with distance from gap center, with survivorship increasing from gap center to forest edge during the first half of the study, and the opposite trend by the end of the experiment.

Contributing to the theme of Restoring Forest Landscapes of the Future, Riccioli et al. (2019) evaluated the willingness to pay for restoration management to maintain the recreational values of forests. Forest users preferred the use of management leading to high forests versus natural evolution, suggesting the increasing importance of recreational value toward motivating forest restoration in the future.

In conclusion, we recognized the importance of continued commitment to multidisciplinary, global collaboration in forest restoration research. Regular gatherings through symposia were identified as an instrumental tool in exchange of experiences and research information, and it was decided that the 4th IUFRO Restoring Forests would be held during 2020 in Chile.

Acknowledgements We are most grateful to all authors of this Special Issue of the 3rd IUFRO Restoring Forests Congress, and for support from The Swedish Research Council for Sustainable Development, EFINORD-SNS Nordic Network of Forest Regeneration, and grant IUT21-4 from the Estonian Ministry of Education and Research. We appreciate constructive comments from three reviewers on this manuscript.

\section{References}

Anderson J, Prescott CE, Grayston SJ (2019) Organic matter accumulation in reclaimed soils under spruce, poplar and grass in the Alberta oil sands. New For. https://doi.org/10.1007/s11056-018-9646-4

Andivia E, Villar-Salvador P, Oliet JA, Puértolas J, Dumroese RK (2019) How can my research paper be useful for future meta-analyses on forest restoration plantations? New For. https://doi.org/10.1007/ s11056-018-9631-y

Berg EC, Zarnoch SJ, McNab WH (2019) Twenty-year survivorship of tree seedlings in wind-created gaps in an upland hardwood forest in the eastern US. New For. https://doi.org/10.1007/s11056-018-9685-X

Bertness MD, Callaway R (1994) Positive interactions in communities. Trends Ecol Evol 9:191-193

Bradshaw RH, Sykes MT (2014) Ecosystem dynamics: from the past to the future. John Wiley \& Sons, Hoboken

Bruno JF, Stachowicz JJ, Bertness MD (2003) Inclusion of facilitation into ecological theory. Trends Ecol Evol 18:119-125

Burney OT, Jacobs DF (2018) Species selection-a fundamental silvicultural tool to promote forest regeneration under high animal browsing pressure. For Ecol Manag 408:67-74

Cernansky R (2018) How to rebuild a forest. Nature 560:542-544 
Chazdon R (2008) Beyond deforestation: restoring forests and ecosystem services on degraded lands. Science 320:1458-1460

Coll L, Ameztegui A, Collet C, Löf M, Mason B, Pach M, Verheyen K, Abrudan I, Barbati A, Barreiro S, Bielak K, Bravo-Oveido A, Ferrari B, Govedar Z, Kulhavu J, Lazdina D, Metslaid M, Mohren F, Pereira M, Pedic S, Rasztovits E, Short I, Spathelf P, Sterba H, Stojanovic D, Valsta L, Zlatanov T, Ponette Q (2018) Knowledge gaps about mixed forest: What do European forest managers want to know and what answers can science provide? For Ecol Manag 407:106-115

Colloff MJ, Lavorel S, van Kerkoff LE, Wyborn CA, Fazey I, Gorddard R, Mace GM, Foden WB, Dunlop M, Prentice C, Crowley J, Leadley P, Degeorges P (2017) Transforming conservation science and practice for a postnormal world. Conserv Biol 31:1008-1017

Corlett RT (2016) Restoration, reintroduction, and rewilding in a changing world. Trends Ecol Evol 31:6

Cortina J, Amat B, Castillo V, Fuentes D, Maestre FT, Padilla FM, Rojo L (2011) The restoration of vegetation cover in the semi-arid Iberian southeast. J Arid Environ 75:1377-1384

Côté SD, Rooney TP, Tremblay J-P, Dussault C, Waller DM (2004) Ecological impacts of deer overabundance. Annu Rev Ecol Evol Syst 35:113-147

Crouzeilles R, Ferreira MS, Chazdon RL, Lindenmayer DB, Sansevero JBB, Monteiro L, Irabarrem A, Latawiec AE, Strassburg BBN (2017) Ecological restoration success is higher for natural regeneration than for active restoration in tropical forests. Sci Adv 3:e1701345

Dalgleish HJ, Nelson CD, Scrivani J, Jacobs DF (2015) Consequences of shifts in abundance and distribution of American chestnut for restoration of a foundation forest tree. Forests 7:4

Dumroese RK, Williams MI, Stanturf JA, Clair JBS (2015) Considerations for restoring temperate forests of tomorrow: forest restoration, assisted migration, and bioengineering. New For 46:947-964

Dumroese RK, Landis TD, Pinto JR, Haase DL, Wilkinson KW, Davis AS (2016) Meeting forest restoration challenges: using the target plant concept. Reforesta 1:37-52

Earnshaw KM, Baribault TW, Jacobs DF (2016) Alternative field fertilization techniques to promote restoration of leguminous Acacia koa on contrasting tropical sites. For Ecol Manag 376:126-134

FAO (2010) Planted forests in sustainable forest management: A statement of principles. Food and Agricultural Organisation, Rome

FAO (2018) The state of the world's forests 2018 - forest pathways to sustainable development. Rome. License: CC BY-NC-SA 3.0 IGO

Felton AM, Felton A, Raubenheimer D, Simpson SJ, Krizsan SJ, Hedwall P-O, Stolter C (2016) The nutritional balancing act of a large herbivore: an experiment with captive moose (Alces alces L). PLoS ONE 11:e0150870

Gavinet J, Prevosto B, Fernandez C (2016) Introducing resprouters to enhance Mediterranean forest resilience: importance of functional traits to select species according to a gradient of pine density. J Appl Ecol 53:1735-1745

Giesecke T, Brewer S, Finsinger W, Leydet M, Bradshaw RHW (2017) Patterns and dynamics of European vegetation change over the last 15,000 years. J Biogeogr 44:1441-1456

Gómez-Aparicio L (2009) The role of facilitative interactions in the restoration of degraded ecosystems: a meta-analysis across life-forms and ecosystems. J Ecol 97:1202-1214

Gómez-Aparicio L, Zamora R, Gomez JM, Hodar JA, Castro J, Baraza E (2004) Applying plant facilitation to forest restoration: a meta-analysis of the use of shrubs as nurse plants. Ecol Appl 14:1128-1138

Grossnickle SC, El-Kassaby YA (2015) Bareroot versus container stocktypes: a performance comparison. New For 47:1-51

Gustafson EJ, Sturtevant BR, de Bruijn AMG, Lichti NI, Jacobs DF, Kashian DM, Miranda BR, Townsend PA (2018) Forecasting effects of tree species reintroduction strategies on carbon stocks in a future without historical analog. Glob Change Biol 24:5500-5517

Haase DL, Davis AS (2017) Developing and supporting quality nursery facilities and staff are necessary to meet global forest and landscape restoration needs. Reforesta 4:69-93

Harris JA, Hobbs RJ, Higgs E, Aronson J (2006) Ecological restoration and global climate change. Restor Ecol 14:170-176

He Q, Bertness MD, Altieri AW (2013) Global shifts towards positive species interactions with increasing environmental stress. Ecol Lett 16:695-706

Hobbs RJ (2013) Grieving for the past and hoping for the future: balancing polarizing perspectives in conservation and restoration. Restor Ecol 21:145-148

Jacobs DF, Dalgleish HJ, Nelson CD (2013) A conceptual framework for restoration of threatened plants: the effective model of American chestnut (Castanea dentata) reintroduction. New Phytol 197:378-393

Jacobs DF, Oliet JA, Aronsson J, Bolte A, Bullock JM, Donoso PJ, Landhäusser SM, Madsen P, Peng S, Rey-Benayas JM, Weber JC (2015) Restoring forests: what constitutes success in the twenty-first century? New For 46:601-614 
Jõgiste K, Korjus H, Stanturf JA, Frelich LE, Baders E, Donis J, Jansons A, Kangur A, Köster K, Laarmann D, Maaten T, Marozas V, Metslaid M, Nigul K, Polyachenko O, Randveer T, Vodde F (2017) Hemiboreal forest: natural disturbances and the importance of ecosystem legacies to management. Ecosphere 8:e01706

Johnstone JF, Allen CD, Franklin JF, Frelich LE, Harvey BJ, Higuera PE, Mack MC, Meentemeyer RK, Metz MR, Perry GL (2016) Changing disturbance regimes, ecological memory, and forest resilience. Front Ecol Environ 14:369-378

Krawchuk MA, Moritz MA, Parisien MA, Van Dorn J, Hayhoe K (2009) Global pyrogeography: the current and future distribution of wildfire. PLoS ONE 4:e5102

Kuijper DP, Jędrzejewska B, Brzeziecki B, Churski M, Jedrzejewski W, Zybura H (2010) Fluctuating ungulate density shapes tree recruitment in natural stands of the Białowieża primeval forest, Poland. J Veg Sci 21:1082-1098

Lesko J, Jacobs DF (2018) Conversion of conifer plantations to native hardwoods: influences of overstory and fertilization on artificial regeneration. New For 49:829-849

Lindenmayer DB (2019) Integrating forest biodiversity conservation and restoration ecology principles to recover natural forest ecosystems. New For. https://doi.org/10.1007/s11056-018-9633-9

Löf M (Ed.) (2017) Program and book of abstracts of the IUFRO $3^{\text {rd }}$ restoring forest: regeneration and ecosystem function for the future. Lund, Sweden 12-14 September 2017. Report 51. Swedish University of Agricultural Sciences, Southern Swedish Forest Research Centre, Alnarp, pp 109. ISBN-978-91-576-9517-9

Löf M, Dey CD, Navarro RM, Jacobs DF (2012) Mechanical site preparation for forest restoration. New For 43:825-848

Lu D, Wangd GG, Zhang J, Fang Y, Zhu C, Zhu J (2018) Converting larch plantations to mixed stands: effects of canopy treatment on the survival and growth of planted seedlings with contrasting shade tolerance. For Ecol Manag 409:19-28

Macdonald SE, Landhäusser SM, Skousen J, Franklin J, Frouz J, Hall S, Jacobs DF, Quideau S (2015) Forest restoration following surface mining disturbance: challenges and solutions. New For 46:703-732

Maltoni A, Mariotti B, Tani A, Martini S, Jacobs DF, Tognetti R (2019) Natural regeneration of Pinus pinaster facilitates Quercus ilex survival and growth under severe deer browsing pressure. For Ecol Manag 432:356-364

Mansourian S (2018) In the eye of the beholder: reconciling interpretations of forest landscape restoration. Land Degrad Dev 29:2888-2898

Martín JA, Witzell J, Blumenstein K, Elzbieta R, Helander M, Sieber TN, Gil L (2013) Resistance to Dutch elm disease reduces presence of xylem endophytic fungi in elms (Ulmus spp.). PLoS ONE 8:e56987

Martín JA, Sobrino-Plata J, Rodríguez-Calcerrada J, Collada C, Gil L (2019) Breeding and scientific advances in the fight against Dutch elm disease: will they allow the use of elms in forest restoration? New For. https://doi.org/10.1007/s11056-018-9640-x

Meli P, Holl KD, Rey Benayas JM, Jones HP, Jones PC, Montoya D, Mateos DM (2017) A global review of past land use, climate, and active vs. passive restoration effects on forest recovery. PLoS ONE. https:// doi.org/10.1371/journal.pone.0171368

Merlin M, Leishman F, Errington RC, Pinno BD, Landhäusser SM (2019) Exploring drivers and dynamics of early boreal forest recovery of heavily disturbed mine sites: a case study from a reconstructed landscape. New For. https://doi.org/10.1007/s11056-018-9649-1

Metslaid M, Palli T, Randveer T, Sims A, Jõgiste K, Stanturf JA (2013) The condition of Scots pine stands in Lahemaa National Park, Estonia 25 years after browsing by moose (Alces alces). Boreal Environ Res 18:25-34

Minnemayer S, Laestadius L, Sizer N, Saint-Laurent C, Popapov P (2011) A world of opportunity. World Resource Institute, Report, Washington, DC

Oliet JA, Jacobs DF (2012) Restoring forests: advances in techniques and theory. New For 43:535-541

Oliet JA, Blasco R, Valenzuela P, Melero de Blas M, Puértolas J (2019) Should we use meshes or solid tube shelters when planting in Mediterranean semiarid environments? New For. https://doi.org/10.1007/ s11056-018-9659-z

Owings CF, Jacobs DF, Shields JM, Saunders MR, Jenkins MA (2017) Individual and interactive effects of white-tailed deer and an exotic shrub on artificial and natural regeneration in mixed hardwood forests. AoB Plants 9:plx024

Perring MP, Standish RJ, Price JN, Craig MD, Ericson TE, Ruthrof KX, Whiteleg AS, Valentine LE, Hobbs RJ (2015) Advances in restoration ecology: rising to the challenges of the coming decades. Ecosphere $6: 1-25$

Potter KM, Jetton RM, Bower A, Jacobs DF, Man G, Hipkins VD (2017) Banking on the future: progress, challenges and opportunities for the genetic conservation of forest trees. New For 48:153-180 
Puettmann KJ, Ares A, Burton JI, Dodson EK (2016) Forest restoration using variable density thinning: lessons from Douglas-Fir stands in western Oregon. Forests 7:310

Reid JL, Fagan ME, Zahawi RA (2018) Positive site selection bias in meta-analyses comparing natural regeneration to active forest restoration. Sci Adv 4:eaas9143

Riccioli F, Marone E, Boncinelli FC, Tattoni C, Rocchini D, Fratini R (2019) The recreational value of forests under different management systems. New For. https://doi.org/10.1007/s11056-018-9663-3

Silva LN, Freer-Smith P, Madsen P (2019) Production, restoration, mitigation: a new generation of plantations. New For. https://doi.org/10.1007/s11056-018-9644-6

Spathelf P, Stanturf J, Kleine M, Jandl R, Chiatante D, Bolte A (2018) Adaptive measures: integrating adaptive forest management and forest landscape restoration. Ann For Sci 75:55

Stanturf JA, Schoenholtz SH, Schweitzer CJ, Shepard JP (2001) Achieving restoration success: myths in bottomland hardwood forests. Restor Ecol 9:189-200

Stanturf JA, Palik BJ, Dumroese RK (2014a) Contemporary forest restoration: a review emphasizing function. For Ecol Manag 331:292-323

Stanturf JA, Palik BJ, Williams MI, Dumroese RK, Madsen P (2014b) Forest restoration paradigms. J Sustain For 33:161-S194

UN (2019) Press release New UN decade on ecosystem restoration offers unparalleled opportunity for job creation, food security and addressing climate change. Accessed 2019-03-15 at https://www.unenv ironment.org

Uscola M, Salifu KF, Oliet JA, Jacobs DF (2015) An exponential fertilization dose response model to promote restoration of the Mediterranean oak Quercus ilex. New For 46:795-812

Villalobos A, Olsson G, Birkedal M, Löf M (2019) The effects of four repellents on bank vole consumption and germination of beech nuts and acorns. New For. https://doi.org/10.1007/s11056-018-9660-6

Villar-Salvador P, Puértolas J, Cuesta B, Peñuelas JL, Uscola M, Heredia-Guerrero N, Rey Benayas JM (2012) Increase in size and nitrogen concentration enhances seedling survival in Mediterranean plantations. Insights from an ecophysiological conceptual model of plant survival. New For 43:755-770

Villar-Salvador P, Uscola M, Jacobs DF (2015) The role of carbohydrate and nitrogen remobilization in the growth and stress tolerance of planted forest trees. New For 46:813-839

Wagner RG, Gonzalez-Benecke CA, Nelson AS, Jacobs DF (2018) Forest regeneration in changing environments. New For 49:699-703

Zapico I, Martín Duque JF, Bugosh N, Laronne JB, Ortega A, Molina A, Martín-Moreno C, Nicolau JM, Sánchez Castillo L (2018) Geomorphic reclamation for reestablishment of landform stability at a watershed scale in mined sites: the Alto Tajo Natural Park, Spain. Ecol Eng 111:100-116

Publisher's Note Springer Nature remains neutral with regard to jurisdictional claims in published maps and institutional affiliations.

\section{Affiliations}

\section{Magnus Löf ${ }^{1} \cdot$ Palle Madsen ${ }^{2} \cdot$ Marek Metslaid $^{3,4} \cdot$ Johanna Witzell $^{1}$. Douglass F. Jacobs 5}

1 Southern Swedish Forest Research Center, Swedish University of Agricultural Sciences, 23053 Alnarp, Sweden

2 Forest and Landscape College, University of Copenhagen, Fredensborg, 3480 Copenhagen, Denmark

3 Institute of Forestry and Rural Engineering, Estonian University of Life Sciences, 51006 Tartu, Estonia

4 Norwegian Institute of Bioeconomy Research, 1431 Ås, Norway

5 Department of Forestry and Natural Resources, Hardwood Tree Improvement and Regeneration Center, Purdue University, West Lafayette, IN 47907-2061, USA 